\title{
FUTUROLOGIE EN REKENAARWETENSKAP
}

Ds. Dick Steyn.

\section{DIE OPDRAG}

Hierdie opdrag kan op meer as een wyse geïnterpreteer word. Daar kan bloot gekyk word na die verhouding tussen die twee wetenskappe, wat die gebruiks moontlikhede van die een vir die ander is, of daar kan uit 'n futurologiese hoek na die Rekenaarswetenskap gekyk word.

Die tema sal soos volg aan die orde gestel word. Begrippe word kortliks opgehelder; daar word gekyk na die skopus van die Futurologie; 'n kort evaluering van die rekenaarstegnologie word gegee aan die hand van reaksies, $n l$. 'n ongekende optimisme, 'n somber pessimisme en 'n verantwoordelike houding.

\section{OPHELDENING VAN BEGRIPPE}

Futurologie

Futurologie is die wetenskap wat die hede wil bystuur na 'n wenslike toekoms. Uit hierdie definisie kom 'n hele paar sake baie duidelik na vore: dit gaan om die toekoms; dit is werksaam in die hede; dit het 'n baie sterk etiese inslag; dit is nie besturing van die hede na die toekoms nie, maar bysturing.

\section{Rekenaarwetenskap}

Dit is moontlik beter om te praat van Rekenaartegnologie. Die rekenaar is 'n tegniese middel waaromheen 'n wetenskap gebou is. Met die "logie" uitgang word uitdrukking gegee aan die wetenskap, met die invoeging van "tegno." word uitdrukking gegee aan die rekenaar as 'n stuk tegniek.

\section{Tegniek}

Tegniek is die vormgewing van dooie materie (o.g.v. wetenskaplike kennis of voor-wetenskaplike kreatiwiteit en vindingrykheid) met behulp van gereedskappe en dit gaan van die hamer tot die rekenaar. In die tegniek word die denke van die vormgewer geobjektiveer of verselfstandig. Tegniek is die vormgewing en tegnologie is die wetenskap van die vormgewing.

\section{DIE SKOPUS VAN DIE FUTUROLOGIE}

Die Futurologie bestaan uit drie komponente. Voordat ons egter hierdie komponente aan die orde stel, net eers die volgende stellings:

\section{Stelling 1}

Daar bestaan inderdaad 'n geperverteerde Futurologie, maar daar is ruimte vir 'n verantwoordelike of reformatoriese Futurologie of toekomswetenskap.

Stelling 2

In die natuurwetenskappe word tot op 'n sekere hoogte vanuit vaste natuurwette geredeneer. 


\section{Stelling 3}

By die Futurologie word uitgegaan van die standpunt dat by die mens sekere gedragspatrone waarneembaar is, maar dit kan nie tot noodwendighede verhef word nie.

Stelling 4

Die mens is in sy wese veranderlik en nie veranderbaar nie. In sy wese bly die mens mens en deel van sy menswees is juis dat hy veranderlik is en dus onvoorspelbaar.

Stelling 5

In 'n al groter wordende spesialisasie van die wetenskappe wil die Futurologie 'n generalistiese benadering handhaaf.

Stelling 6

Teenoor 'n al groter wordende opbreking van die kosmiese werklikheid in die wetenskappe, word uitgegaan van 'n holistiese blik op die skepping.

Stelling 7

Beoefening van die Futurologie is spanwerk, eerder as die werk van individeule spesialiste.

Stelling 8

Elke mens behoort aktief betrokke te wees by sy lewe (en sy toekoms) en behoort nie net die passiewe toeskouer te wees van die gebeurtenisse waarvan hy die objek is nie.

Vervolgens kyk ons na die drie komponente van die Futurologie.

\subsection{TENDENSANALISE}

Alhoewel die toekoms deel is van die kosmiese geskape werklikheid van die tydsheid van die skepping, is die toekoms nie veld van ondersoek vir hierdie wetenskap nie. Die verlede en die hede is die veld van ondersoek. Daar word gedragspatrone, ontwikkelingspatrone en tendense waargeneem en met behulp van o.a. die rekenaar word gesimuleer waarheen tendense waarskynlik in die toekoms kan lei hoewel dit nie noodwendig daarheen sal lei nie. Menslike kultuur verloop nie volgens vaste noodwendighede nie. "Trends is no destiny" (Mumford).

Tendense dui nie noodwendig die bestemming aan nie, maar tendense kan veelseggend wees.

'n Pragvoorbeeld van tendensanalise vind ons by die Amerikaner John Naisbitt (1982) in sy "Megatrends". Met behulp van die rekenaar maak hy ' $n$ analise van twee miljoen artikels in plaaslike koerante oor plaaslike aangeleenthede oor 'n tydperk van twaalf jaar, op 'n basis van die aktualiteit en die ruimte wat dit in die koerante in beslag neem en hoedat dit dan plek maak vir ander aktuele sake. Dit is ' $n$ metode van tendensanalise wat reeds sedert die Tweede Wêreldoorlog besonder akurate gegewens voorsien. Op die wyse kan Naisbitt tot die konklusie kom dat daar in Amerika tans so 'n tiental dominante tendense in die algemene kultuurpatrone waarneembaar is. 
Wat is nou die betekenis van die tendensanalise?

3.1.1 Daarmee word duidelik waarneembare tendense geĩndentifiseer.

3.1.2 Dit gee geleentheid om tendense te evalueer en te stimuleer waar nodig.

3.1.3 Dit signaleer watter tendense katastrofies kan wees as dit onbelemmerd sou voortgaan.

3.1.4 Dit gee 'n aanduiding van leemtes en ruimte vir verandering en verbetering.

3.1.5 Dit verskaf insig waarom korrektiewe optrede in die verlede geslaag of mislúk het.

\subsection{ETIESE EVALUERING}

'n Besluit oor die toekoms gaan nie om die seleksie van alle moontlikhede om dan net die moontlikheid met die grootste potensiaal te kies nie. Dit gaan ook nie om die vraag: Wat moet ons doen met die toekoms wat op ons aanstorm nie? Die toekoms is nie die onaantasbare nie, dit is nie allesverowerend en onderwerpend nie. Die toekoms (hoe dit ookal daar sal uitsien) dwing ons nie tot 'n oorleweringsetiek nie. Die vraag is nie wat moet ons met die toekoms doen nie, maar die vraag is wat moet ons in die hede met die hede doen om dit by te stuur na 'n wenslike toekoms?

Hierdie besluit en keuse word gedoen in die lig van ons verantwoordelikheid voor God. God roep die mens om die skepping (natuur en kultuur) te bou en te bewaak. God roep en die mens antwoord deur in verhouding met die skepping te tree op so 'n wyse dat die skepping nie uitgebuit, besoedel of uitgeput word nie en dat mense nie in konfrontasie met mekaar te staan kom nie. Ons neem deel aan die gebalanseerde uitbou van die skepping waar mens en mens en mens en res van die skepping in harmonie met mekaar bestaan, op so 'n wyse dat die Skepper in die sentrum van sy ganse skepping staan. Ons bou nie net nie, maar ons bewaar ook. Die mens is geen HOMO CREATOR, wat werke verrig wat tot aan die hemel sterk nie ('n Babelkultuur bou nie), maar ons is geroepenes op weg om gestalte te gee aan 'n nuwe Jerusalem-kultuur, waar God in die sentrum staan. Ons toekomskeuses word Coram Deo - voor die aangesig van God gedoen.

Wat wenslik is word in die lig van die Skrif vasgestel. Uit die waarneembare tendense moet geselekteer word wat eties goed en wat eties slegs is. Met die wenslike gaan dit nie om 'n einddoel nie, maar om die evaluering van die hede en om rigtingwysers vir die toekoms aan te wys.

Die betekenis van die etiese evaluering?

3.2.1 Ons stel vas wat wenslik vir die toekoms is in die lig van die Skrif.

3.2.2 Ons stel vas wat waardeloos en wat waardevol is.

3.2.3 Ons stel vas wat teëgewerk moet word en wat gestimuleer moet word. 


\subsection{BEPLANNING}

Hierdie komponent word die toegepaste fase genoem. Weten-kap is al vir 'n dekade of twee nie meer 'n ivoortoringstokperdjie, wat weinig waarde vir die praktyk het nie. Wetenskap behoort 'n betrokke wetenskap te wees. Dit moet die opset hê om praktyk toe te gaan met sy kennis.

Met die etiese evaluering het dit gegaan om wat wenslik is vir die toekoms. Nou gaan dit om die vraag hoe om die bysturing van die hede te doen op weg na die wenslike.

By beplanning skuil 'n baie groot gevaar. Kultuur verloop nie volgens vaste noodwendighede nie. Kultuur behoort ook nie die nastrewe van vooropgestelde ideale te wees nie. Ook kultuur behoort Coram Deo beoefen te word. Daar behoort dag vir dag keuses gemaak te word en rigting aangedui te word. Ideale wat in die kultuur fanaties nagestreef word verloop gewoonlik langs 'n dialektiese proses en eindig op idole (afgode) wat sy kinders verteer. Dit verk net anders uit as wat beplan is. Daarom geskied beplanning nie met die oog op die realisering van bepaalde groot ideale nie, want dan moet ons noodwendig ook beplan vir mislukking.

Met die regte perspektief op die mens en alle menswerk word die orde omgekeer. Beplanning geskied in die lig van die feit dat ons nie Homo Creator is nie;

dat ons geroepenes is om die Bybelse beginsels gestalte te gee in hierdie wêreld (sout, lig);

dat die hele skepping, mens en natuur eiendom van God is; dat die gelowiges reeds noual volk van God is (Koninkryk van God het gekom); dat daar ook nog die element van die "nog-nie" aanwesig is, m.a.w. die kwaad is 'n nie-wegwensbare deel van die werklikheid; dat ons die volmaakte nie nou kan verwesenlik of verwag nie.

Beplanning het 'n instrumentele karakter om aan ons verantwoordelikheid op 'n sinvolle wyse gestalte te gee. Ons beplan nie om kinders van God in die wêreld te word nie. Ons beplanning geskied in die lig van die feit dat ons kinders van God is en beplanning het nou ten doel om aan te dui hoe ons daaraan gestalte kan gee.

Die betekenis van beplanning?

3.3.1 Dit dui rigting aan hoe die openbaarmaking van die kinders van God aan die ganse skepping kan geskied;

3.3.2 Hoe die bysturing van die hede na die wenslike toekoms moet plaasvind.

Let tog daarop, ons beplan nie vir ideale nie, nie utopië nie, maar ons beplan vir die korrekte manier van doen, vir wenslike kultuurbeoefening in die toekoms.

Ten slotte die opmerking: Daar is ook so iets soos 'n geperverteerde Futurologie, waar die mens vergoddelik word, wetenskap en tegniek as middele gesien word wat die mens onoorwinlik maak en waar die geloof heers dat alles net beter sal word as die middele net korrek aangewend word. Daar heers self die opvatting dat die eskatologiese mens met behulp van die tegniek en wetenskap gearriveer het. 


\section{FUTUROLOGIESE EVALUERING VAN DIE REKENAARTEG- NOLOGIE}

$\mathrm{Na}$ regte behoort hierdie afdeling vanuit die drie komponente van die Futurologie aangepak te word, nl. tendensanalise, etiese evaluerring en beplanning. Dit word egter ietwat anders gedoen. Ons kyk na verskillende reaksies wat alreeds ' $n$ bepaalde evaluering verteenwoordig. Dan kyk ons na die rekenaarstegnologie vanuit die hoek dat daar ' $n$ ongekende optimisme en 'n somber pessimisme heers en dat daar ook 'n verantwoordelike houding moontlik is.

\section{1 'n Ongekende Optimisme}

In sekere kringe heers daar ongekende optimisme oor die moontlikhede wat die rekenaar inhou vir toekomsbeplanning en toekomsbesturing, veral d.m.v. organisasie en informasie. In die tegnokratiese denkklimaat is die rekenaar die beste ding wat kon gebeur het, want met die rekenaar het die volkome selfstandige mens gearriveer. Met die rekenaar word die droom van die selfstandige mens as skepper en onderhouer van sy lewe en toekoms waar. Oor die tegniese middele beskik ons nou, al wat ons nou moet doen is om op 'n wetenskaplike wyse goeie beplanning en goeie besturing te kry en die toekoms is vas en seker. Die entoesiasme oor die rekenaar ken in sekere kringe geen perke nie. Gerobotiseerde arbeid (dit is werk wat deur 'n rekenaar-geprogrammeerde masjien gedoen kan word) kan 'n klomp sleurwerk en vuilwerk wegneem van die skouers van die mens en daardeur kan die mens meer waardigheid in sy arbeid en meer vrye tyd geniet. Die ideaal van die homo ludens (die spelende mens) is nie meer buite bereik nie.

'n Geldlose maatskappy, waar die mens nie eens meer 'n kredietkaart nodig sal hê nie word in die vooruitsig gestel. Slegs 'n mikrokode onder jou vingernael kan jou identiteit en koopkrag oor die hele wêreld waarborg.

Wêreldwye alokering van natuurlike hulpbronne kan d.m.v. die rekenaar gedoen word en eweredige ontginning en verspreiding daarvan kan op die wyse gewaarborg word.

Universele planne kan nou opgestel word vir die ontwikkeling en beheer van die menslike beskawing. Hierdie planne kan tot uitvoer gebring word deur informasie en organisasietegnieke wat deur die rekenaar moontlik gemaak word.

Die inrigting van kantore sal oorbodig word m.b.v. die sg. "electronic cottages", waar nie eens 'n sekretaresse nodig sal wees nie. Haar werk word gedoen deur antwoordmasjiene, databanke en rekenaars met kunsmatige intelligensie.

Die D.N.A.-rekombinanttegnologie wat m.b.v. die rekenaar al die data oor die genes van die mens op rekord kan plaas, sal dit in die toekoms moontlik maak dat die mediese tegnoloog defekte by die mens betyds kan uitskakel. Babas volgens voorskrif en bestelling is nie buite die bereik van die mens nie. Kloonvorming word as ' $n$ moontlikheid genoem en die moontlikheid van genetiese manipulasie is meer as net bespiegelinge. So kan ons voortgaan om 'n hele katalogus op te stal van dinge wat tien-vyftien jaar gelede na wetenskaps- 
fiksie sou klink en wat vandag werklikheid is. Die geweldige prestasies van die wetenskap en tegnologie veroorsaak dat daar geen perke is aan die optimisme oor die toekoms en die rol wat die rekenaar daarin sal speel nie. Daarmee wil ons nie sê dat daar nie ook veel is om te waardeer in die rekenaartegnologie nie, maar ons moet erken dat daar groot gevare in skuil. Ons moet begrip hê dat 'n oormoedige mens met so 'n magtige middel tot sy beskikking net vir homself en vir die res van die skepping gevare sal inhou. Die oormoedige mens glo dat hy nou met die hulp van die rekenaar in staat is om 'n toring te bou wat tot aan die hemel strek en dat niks meer vir hom onmoontlik sal wees nie. In die denkwêreld van die tegnokrasie word alreeds gesê: Wat die mens wil doen, dit kan hy ook doen en wat hy kan doen, dit mag hy ook doen. Dit beteken, enigiets wat die mens vandag wil doen is tegnies moontlik en as die tegnies moontlik is, dan is dit wenslik, dan is dit eities goed.

\section{2 'n Somber Pessimisme}

Teenoor die tegnokratiese ekstase oor die rekenaartegnologie, tegniek en wetenskap, kry ons 'n somber pessimisme, wat by sommige so erg is dat mense geen lig meer sien nie, en dat hulle geen hoop vir die toekoms het nie. Belangrike kritiek teen die tegnisistiese gemeenskap kom uit die hoek van die Neo-Marxisme. Een van die wrang vrugte van 'n tegnisistiese gemeenskap is die vervreemding van die mens. Ons moet in gedagte hou dat die hoeksteen van 'n tegnisistiese gemeenskap die rekenaar is. Die ontmensliking van die mens blyk daaruit dat dit nie vreemd is om vergelykings te $\mathrm{kry}$ waar die mens met die rekenaar vergelyk word, in plaas daarvan dat die rekenaar met die mens vergelyk word nie.

In sekere opsigte word die mens minderwardig gestel teenoor die rekenaar.

Op die produksielyn word kwaliteit in sy konstantheid gewaarborg as die produksieproses gerobotiseer is. Die rekenaar is eintlik die een wat die betroubare werk lewer en die mens is hoogstens bediener van die rekenaar. Rekenaars maak nie foute nie, mense wel, daarom, as iets fout gegaan het is dit die programmeur of bediener se fout.

Kreatiwiteit en inventiviteit by mens word grootliks onderdruk deur die rekenaar. In die verlede is groot uitdagings aan die mens gestel. Dit is juis hierdie uitdagings wat hom gestimuleer het om oplossings te soek. Kontroleer maar hoeveel uitvindinge in die verlede 'n antwoord was om fisieke arbeid van die mens ligter te maak. Kreatiwiteit kan maklik deur die rekenaar beperk word tot verfyning van prosesse.

Die Neo-Marxisme bied in der waarheid nie 'n oplossing vir die probleme van 'n tengisistiese gemeenskap nie. Hulle voel hulle magteloos teenoor die invloed van die tegniek en neig dan tot vernietiging as oplossing. Hulle sien die rekenaar as net nog 'n instrument wat die bestaande orde en die "establishment" verder gaan versterk.

Die denkers van die sg. Teenkultuur met name Roszak en Reich kom ook met belangrike kritiek teen die tegnisistiese kultuur. As ons 
praat van 'n tegnisistiese kultuur, dan is die rekenaar nie net 'n integrale deel daarvan nie, maar dit is die hart daarvan. Roszak sê dat die opkoms van die teenkultuur verstaan moet word uit die ervaring van sinloosheid en wanhoop temidde van 'n tegniese kultuur en 'n sterk ontwikkelde, hiper-spesialistiese wetenskapsbeoefening wat die integrale kennis van die mens ophef. Die teenkultuur is op soek na gemeenskap, outentisiteit en sin te midde van sosiale ontworteling, vervreemding en sinloosheid. Hulle roep dan om reddende terugkeer na die diepte, na die mitiese, die visionêr bronne van egte kultuur. Daar moet ruimte wees vir subjektiewe kennis, wat te vinde is in die verbeelding, intuisie, wysheid, misterie, ingewing, inspirasie, ekstase, kontemplasie, meditasie, mite, passie, die onuitspreeklike die mistieke, die heilige, die gnosis. Dit gaan nie om veel te weet nie, maar om diep te ken.

Doelbewus word dan gesoek na 'n oplossing in die rigting waar die reusagtige teruggebring word deur die kleinskalige, variasie in plaas van nivellering, meer organies as meganies, eenvoud en suinigheid moet oorvloed vervang en veelsinnige vreugdevolle arbeid wat in die plek van onpersoonlike, vervreemdende produktiewe arbeid moet kom. Binne hierdie denkklimaat kry ons dan dikwels die "backto-basics" en die "back-to-nature" gedagte. Uit die aard van die saak word die rekenaar ook beskou as een van die vervreemde elemente van die tegnisistiese kultuur.

Daar is ook nog 'n derde vorm van pessimisme oor die rekenaar, wat as religieus-aspokalipties getipeer kan word. Die rekenaar word gesien as die wegbereider van die anti-Christus, die instrument om mense te manipuleer en te beinvloed.

Die bekende Franse christelike denker oor die tegnologie, Jacques Ellul is eintlik ook in die kraal van die pessimistiese denkers oor die tegnologie. Hy voel hom totaal magteloos teenoor die tegnologiese ontwikkeling en al oplossing wat oorbly is eintlik onttrekking daaraan en vervreemding daarvan.

\section{3. 'n Verantwoordelike Houding}

'n Mens mag nie blind wees vir die potensiaal wat die rekenaar vir die mens en die beskawing inhou nie. Daar is inderdaad interessante en opwindende moontlikhede wat deur die rekenaar vir die mens geopen word. Aan die ander kant, omdat daar inherent gevare aan die rekenaar verbonde is of omdat grootskaalse misbruik van die rekenaar katastrofaal vir die mensdom kan wees, of die kleinskalige gebruik van die rekenaar ook verslawend en vervreemdend op die mens inwerk, kan ons nie maar 'n rekenaarstormloop organiseer of deelneem daaraan nie. Ons sal van die kant van die teologie moet poog om perspektief op die mens, die roeping van die mens en perspektief op die rekenaar en die tegniek baie duidelik te formuleer.

Ons neem nie maar 'n tussenposisie in om aan die een kant te geniet en te gebruik en aan die ander kant is ons ook versigtig vir die misbruik van die tegniek nie. Dan maak ons ons skuldig aan die grootste dwaling ten opsigte van die tegniek en die rekenaar, en dit is dat dit 
bloot net 'n neutrale instrument is, wat reg gebruik kan word of wat misbruik kan word. Voorts fouteer ons dan deur te dink dat die regte gebruik van die rekenaar noodwendig altyd net goeie gevolge sal hê en die foutiewe gebruik van die rekenaar altyd net slegte gevolge sal hê. Dan is ons vasgevang in die gedagte dat ons met ons regte dade die wêreld bestuur. $U$ onthou dat ons telkens van bystuur gepraat het. Ons erken die Almag en regering van God, maar binne sy voorsieninge beskikking het $\mathrm{Hy}$ ook die mens met sy verantwoordelike roepingsvervulling opgeneem. Alles verloop egter nie kousaal nie, en selfs al word die rekenaar reg gebruik is die resultate van die gebruik nie noodwendig goed en reg nie.

Die mens is nie vasgevang tussen tegniese oormag en menslike onmag nie. Die mens is ook nie volkome in beheer van alles nie. Tog het ons 'n roeping om te heers oor die skepping, op so 'n wyse dat God Koning van Sy skepping sal wees. Die ganse skepping, rekenaar en tegniek, is gawes van God. As dit 'n gawe is, hou dit ook 'n opgaaf in. Daarom is dit heeltemal ter sake om op te let wat met die rekenaar gedoen word - die gebruik of misbruik daarvan. Van 'n gawe moet ook rekenskap gegee word van wat daarmee gedoen is. My gebruik van die rekenaar moet voor God verantwoord kan word, dat dit goed was. Menslike arbeid wat in wetenskap, tegniek en kuns verrig word, in gehoorsaamheid aan die Woord van God is die boustene wat deur God gebruik word vir die Nuwe Jerusalem.

Dit gaan egter nie net om gebruik of misbruik van die rekenaar nie. Ons perspektief moet ook verder gaan.

Die rekenaar is nie 'n neutrale instrument nie. Dis nie maar bloot 'n onskuldige tegniese middel, wat slegs reg of verkeerd gebruik kan word nie. Egbert Schuurman het in sy boek "Middel of Moloch" 1980, breedvoerig ingegaan op hierdie saak.

Tegniek het ons gedefinieer as die vormgewing van dooie materie (o.g.v. wetenskaplike kennis of voorwetenskaplike kreatiwiteit of vindingrykheid) met behulp van gereedskappe en dit gaan van die hamer tot die rekenaar. Die wetenskaplike teorië op grond waarvan tegniese middele ontwerp is, is nie objektief en waardevry nie. Daaroor is daar tog seker nie meer twyfel, dat daar nie so iets soos objektiewe waardevrye wetenskap bedryf kan word nie. Persoonlike en maatskaplike kondisies speel ' $n$ rol in die vorming van teorië. Ten diepste is alle teorië religieus gefundeer, al is dit net 'n geloof dat die teorië neutraal en objektief en waardevry is. In die vormgewing van teorië in tegniek en die rekenaar kry jy 'n objektivering van hierdie religieus - gefundeerde, nie objektiewe, nie waardevrye teo rië. Ons moet besef dat die ingenieur wat die rekenaar ontwerp, 'n mens is, wat kortsigtig is en wat gebreke het en by die ontwerp van sy rekenaar met allerhande invloede te doen het. By die rekenaar het ons eintlik met 'n dubbele inset te doen. Afgesien van die objektivering en gedagtes van die ontwerper, is daar ook nog 'n programmeur, wat ook nie waardevry optree nie, wat ook mens is, wat ook kortsigtig is en met allerhande invloede te doen het. Rekenaars van formaat word nie deur enkelinge ontwerp, gebou of geprogram- 
meer nie. Daar word in spanverband gewerk, waar die enkele programmeur nie eens meer 'n oorsig het oor die totaal van programme wat uiteindelik ingevoer word nie. Eintlik het ons by die rekenaar nie meer met 'n enkelvoudige instrument te doen nie, maar met ' $n$ onderling samehangende en onoorsigtelike sisteem. Die eindverbruiker tree dan in 'n vertrouensverhouding met hierdie sisteem, waarvan hy geen oorsig meer het nie. Hy moet hom in vertroue oorgee aan 'n sisteem, waarvan hy geen oorsig het nie, en op die wyse doen hy dan afstand van 'n belangrike deel van sy verantwoordelikheid. Hy gee hom oor aan 'n instrument, hoewel hy iself nie begryp wat daarin verselfstandig is nie. As iets onoorsigtelik is kan ek moeilik verantwoordelikheid aanvaar vir die resultate wat met hierdie instrument bereik kan word. Oorgawe sonder oorsig kom neer op die prysgawe van verantwoordelikheid.

Die gevaar van die rekenaar lê nie net in die misbruik daarvan alleen nie. By die vroeëre ambagtelike tegnieke (die hamer) was dit nog oorsigtelik. Jy kan besluit of jy die hamer gaan gebruik om 'n spyker in te slaan en of jy iemand se toon daarmee wil slaan. Jy kan voorsien wat gaan gebeur as jy oor die grens van die instrument gaan tree. Met die rekenaar is dit nie meer die geval nie. Deur ander partye is grense en potensiaal ingebou wat jy nie meer weet waartoe dit kan lei by die gebruik (let wel, nie noodwendig misbruik) daarvan nie. Die gewone gebruik van die rekenaar kan lei tot die onvermoede, die onvoorsiene en die onverwagte.

Op hierdie stadium soek 'n mens nog na antwoord op die problematiek. Enkelvoudige en eenvoudige antwoorde bestaan daar nie.

Die antwoord lê nie in 'n beeldestromloop nie. Die antwoord lê ook nie daarin dat die rekenaartegnologie sal voortgaan om self die norme en grense van die ontwikkeling van die rekenaar vas te stel nie. Dan geld die norm wat kan, mag ook. Daar is inderdaad 'n geweldige probleem wat ontstaan het. Die rekenaarstegnologie ontwikkel teen ' $n$ rasende snelheid. Van die kant van die teoloë en die etici is 'n oorverdowende stilte. Daar moet doelbewus gewerk word aan die stel van normering alreeds by die ontwerpstadium en nie net by die gebruikstadium nie anders kan die rekenaar wat elemente van die demoniese inhou, werklike 'n demoniese mag word.

Ons sal moet probeer om die geweldige dinamiek waarmee hier. die tegniek ontwikkel af te rem sodat daar ruimte kan kom vir etiese besinning. Die ontwerp van die rekenaar sal so gehou moet word dat die eindgebruiker verantwoordelikheid vir sy dade kan aanvaar.

Ons sal hande en voete moet gee aan die genormeerde ontwikkeling van die rekenaartegnologie. Daar kan van ons kant af nooit 'n abdikasie van die verantwoordelikheid teenoor ons Skepper plaasvind nie, al is die mag hoe groot en bedreigend. 


\section{BIBLIOGRAFIE}

Du Plessis, P. G. W. Toekomskunde as Morele verantwoordelikheid. Koers 42,5 1977.

Duvenage, B. (Redakteur) 1984: Wetenskap en Woord. Potchefstroom: Departement Wetenskaps leer. Potchefstroomse Universiteit vir CHO.

Ellul, J. 1984: The Technological Society. New York: Vintage Books.

Goudzwaard, B. 1981: Genoodzaakt goed te wezen. Kampen: J. H. Kok.

Naisbitt, J. 1984: Megatrends. Utrecht/Antwerpen: Het Spectrum.

Schumacher, E. F. 1979: Hoe kleiner hoe beter. Baarn Amboboeken.

Schuurman, E. 1980: Techniek Middel of Moloch. Kampen: J. H. Kok.

Schuurman, E. 1985: Tussen Technische Overmacht en menscl jke onmacht. Kampen: J. H. Kok.

Smit, T. C. ea., 1976 Gesprek met die Toekoms. Potchefstroom: Potchefstroom Universiteit.

Toffler, A. 1970: Future Shock. London: Pan Books.

Toffler, A. 1980: The Third Wave. London: Pan Books.

Douma, J. en Velma, W. H. 1979: Ethiek en pelgrimage. Amsterdam: Ton Bolland.

Van der Graaf, M. H. K. (Redakteur) 1984: De crises van de technocratie en het alternatief van de sociocratie. Amersfoort: De Horstink.

Van Steenbergen, B. 1984: De Post-Materialistische Maatschappij. Amersfoort: De Horstink. 